\title{
Research on the Strength of Roadheader Conical Picks Based on Finite Element Analysis
}

\author{
Xueyi $\mathrm{Li}^{1}$, Yonggang Lv${ }^{1}$, Qingliang Zeng ${ }^{*}, 1$ and Jintao Wang ${ }^{2}$ \\ ${ }^{I}$ College of Mechanical and Electronic Engineering, Shandong University of Science and Technology, Qingdao, China \\ ${ }^{2}$ National Institute of Metrology, Beijing, China
}

\begin{abstract}
This paper presents finite element analysis of the strength of roadheaher conical picks. Failure forms of conical picks are investigated, and the FE model of conical pick is established based on ANSYS. The static analysis is carried out according to the load calculated by empirical formula and the deformation map and stress distribution are obtained. The results show that the maximum stress of conical pick appeared in the tool bit. In order to examine the result of static analysis, contact analysis of conical pick cutting process is researched and a consistency is achieved. The finite element analysis not only offers a new way of studying the strength of conical picks and improving the service life of the pick but also provides a reliable theoretical basis for the selection, design and use of the conical picks.
\end{abstract}

Keywords: Roadheader, statics analysis, contact analysis, conical picks, finite element analysis, strength.

\section{INTRODUCTION}

Cutting picks are tools that act on roadheader cutting head and coal excavator roller directly, which is used for breaking coal and rock. The performance of cutting picks has a direct impact on the work efficiency, reliability and service life, as well as on economic efficiency of the whole machine. Due to the rugged working environment of cutting head, the wear and damage of cutting picks are significant; therefore cutting picks have become one of the most vulnerable parts which need to be replaced frequently. According to the statistics, the consumption quantity of cutting picks is 400 to 800 per ten thousand tons of coal mining in our country, and using efficiency of picks is generally low [1].

Many scholars have conducted a lot of research regarding the strength, performance, and service life of cutting picks. Ning et al. [2] analyzed the stress of conical picks of coal cutter by using ANSYS and discovered the stress distribution diagram for conical picks. Ji et al. [3] conducted a stress analysis on cutting tooth through finite element analysis software ANSYS and calculated maximum stress and maximum deformation of the cutting tooth. An [4] studied the strength characteristics of cutting picks with various shapes by using LS-DYNA. Li et al. $[5,6]$ studied the impact of point-attack pick shapes on picks' strength, and analyzed the stress of picks by using ANSYS software and experimental researches. O Su et al. [7] and J Rojek et al. [8] researched on the rock cutting process by numerical simulation using the discrete element method. K G Hurt [9] researched on cutting efficiency and life of rock-cutting picks in rock-cutting testing.

*Address correspondence to this author at the College of Mechanical and Electronic Engineering, Shandong University of Science and Technology, Qingdao, China; Tel/Fax:++0-532-860-57055; E-mail: qlzeng@163.com
However, the domestic researchers have conducted the analyses on cutting picks by using ANSYS based on the loads of theoretical formula, however, these have not been proven to be true and have not been accepted by public yet. The foreign researchers mostly conduct studies through field test and numerical simulation are mainly focused on the rock cutting process, and not on the cutting picks. Therefore, this paper discusses the failures of conical picks and analyzes the force on conical pick by theoretical calculation firstly, and on this basis, it builds the static finite element model and calculates the strength of the conical pick. In order to check the accuracy of the simulation results, the real cutting model of conical pick is built using contact analysis, and this result is compared to the static finite element analysis.

\section{FAILURE FORMS OF CONICAL PICKS}

Conical picks are comprised of the cutter bar and alloy tool bit. The cutter bar is generally made of alloy structural steel and the tool bit is a hard alloy used in the manufacturing. When roadheader works, alloy tool bit directly interacts with the rock in cutting process so it should have sufficient hardness and wear resistance. The cutter bar is used for supporting the alloy tool bit and for connecting it with pick holder, which is fixed together by welding to form conical picks. Cutting picks often encounter hard mineral aggregates such as coal gangue under high compressive stress, shear stress and impact load in cutting process. Therefore working condition of conical picks is so complex that failures are inevitable.

\subsection{Wear of Conical Picks}

With the increase in the cutting time, the frictions of picks and coal and rock make the cutting tip blunt in the process of cutting [10], as shown in Fig. (1a). 


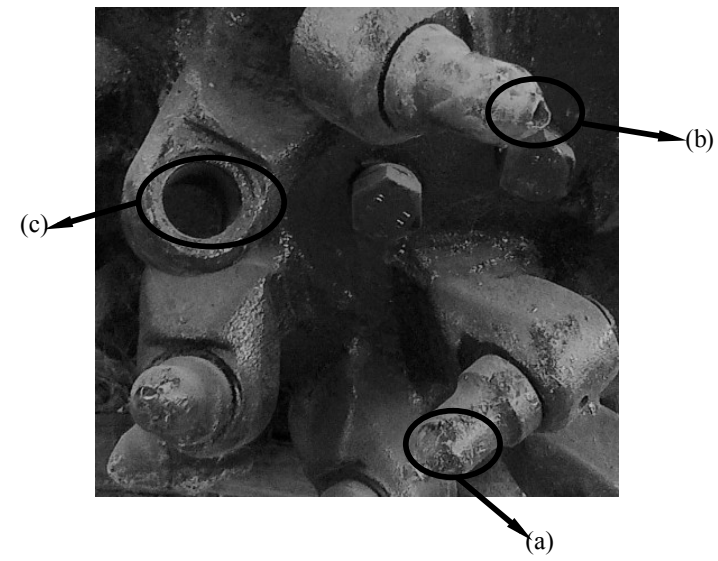

Fig. (1). Picture of failure forms of conical picks.

Depending on the theory of wear, coal-to-metal wear belongs to the abrasive wear. Hard minerals in coal (such as quartz, pyrite, etc.) are the main causes of abrasive wear in the state of dry friction. After bearing, the area of cutting part increases, which results in cutting resistance, decrease in cutting pick strength and increase in the amount of dust [11]. The wear surface of the cutting tools produces $600-800^{\circ} \mathrm{C}$ high temperature due to wear heat during the cutting process of rock and coal, however the periodicity rotational motion of conical picks warms when it contacts with coal and rock and cools when it deviates from the coal and rock, making high-temperature tempering on the top of conical pick and the tissue temper sorbite and ferrite generally. So the hardness of conical picks reduces up to $50 \%$ which accelerates the wear of conical picks. The corrosion wear also appears due to the corrosion of underground environment medium.

\subsection{Cemented Carbide Tool Bit Falls Off}

The cemented carbide tool bit on top of conical picks falls off when the wear of conical picks reaches a certain degree, as shown in Fig. (1b). The cause of the fall off of the tool mainly includes two aspects: (1) Welding quality problems, such as sand inclusion on the welding point, micro crack, and cold solder joint. (2) Strong shock load occurs when the conical pick cutting coal and rock result in stress concentration on the conical pick, and the repeated shock leads to loosening of cemented carbide tool, until the carbide tool falls off. The conical picks cutting with pick body after cemented carbide tool bit falls off and the cutting resistance becomes greater, which results in heavy wear accelerating the damage of conical picks.

\subsection{Conical Picks Loss}

In the process of actual use, loss of conical of picks is also a common problem, which can be shown in Fig. (1c). The loss is mainly because of conical picks not being fixed reliably enough as well as the wear of fixed device.

In addition, the break off of pick body, bending of picks, and some other failure forms of conical picks occur during working process of conical picks. In order to avoid the damage of the picks, the force on conical picks should be known in cutting process firstly.

\section{FORCE ANALYSIS OF CONICAL PICK}

The conical picks suffer from cutting resistance, tractive resistance, and lateral resistance during the cutting process. However, the loads on conical picks are nonlinear due to the nonlinear material and nonlinear contact of coal and rock, and it is very difficult to calculate precise loads on conical picks. The formula given as follows is often used to calculate the force of conical picks based on reference [12]

$$
\left\{\begin{array}{l}
P_{z}=\sigma\left[1.5 k_{1} k_{2}(0.25+0.18 t h)+0.1 S\right] \\
P_{y}=P_{z}(0.15+0.00056 \sigma) 2.5 / h^{0.4} \\
P_{x}=P_{z}[1.4 /(0.3+h)+0.15] h / t
\end{array}\right.
$$

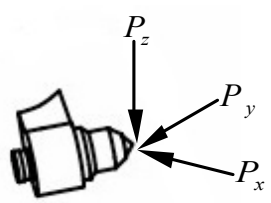

Fig. (2). Force diagram of conical pick.

where $P_{z}, P_{y}$, and $P_{x}$ are cutting resistance, tractive resistance, and lateral resistance on conical pick $(\mathrm{N})$ which is shown in Fig. (2), $\sigma$ is the contact strength of rock (MPa), $k_{1}$ is the geometrical shape coefficient of conical pick, $k_{2}$ is the head shape coefficient of conical pick, $t$ is the average transversal spacing $(\mathrm{mm}), h$ is the average cutting thickness $(\mathrm{mm})$, and $S$ is the projected area of conical pick after blade surface in the traction direction $\left(\mathrm{mm}^{2}\right)$.

\section{STATICS ANALYSIS OF STRENGTH OF CONICAL PICK}

In order to analyze the strength of conical picks, statics analysis of coal cutting is conducted using ANSYS firstly. The force on conical pick is considered as simplified concentrated force according to loading characteristics of conical picks during actual cutting process and does not consider the effect of dynamic load. The assumptions are made as follows:

(1) See the cutter bar and the tool bit as a whole,

(2) Do not consider the rotation of conical picks on toothholder,

(3) Conical picks under concentrated loads focus on all the nodes $3 \mathrm{~mm}$ to the tool bit of picks.

\subsection{Finite Element Modeling and Meshing of Conical Pick}

The solid model of conical pick is built with structure parameter as: the length of pick is $135 \mathrm{~mm}$, the maximum diameter is $65 \mathrm{~mm}$, the length of tool bit is $15 \mathrm{~mm}$, and the diameter of cutter bar is $38 \mathrm{~mm}$. The material parameters are defined as: elasticity modulus is $670 \mathrm{GPa}$, Poisson ratio is 0.3 . Solid $\backslash 10$ node 92 unit is selected for analysis and the conical pick is meshed with smart size (level 6) and the part of tool bit is refined, yielding 29606 nodes and 19005 elements. 


\subsection{Loading and Constraint of Conical Pick}

The analysis type is defined as static. The cutting resistance, tractive resistance, and lateral resistance on conical pick are calculated according to equation (2), and the cutting resistance is found to be $6.5 \mathrm{kN}$, the tractive resistance is $3.2 \mathrm{kN}$, and the lateral resistance is $1.8 \mathrm{kN}$. The load is applied to all the nodes $3 \mathrm{~mm}$ to the tool bit of picks, and DOF is set in the root of the conical pick. The finished finite element model with load and constraint is shown in Fig. (3).

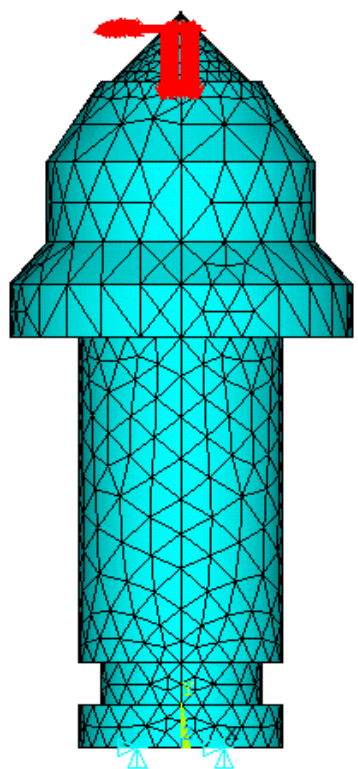

Fig. (3). Load and constraint of conical pick.

\subsection{Solving and Result Analysis}

After all the settings mentioned above, the analysis is carried out to give the result as shown in Figs. $(\mathbf{4}, \mathbf{5})$. Def + Undeformed form is adopted in the display mode of deformation figure to consider the deformation of conical pick intuitively, where imaginary lines are the shape of conical pick before deformation and the others are the results after deformation. It can be seen that the main deformation occurs in the top area of conical pick.

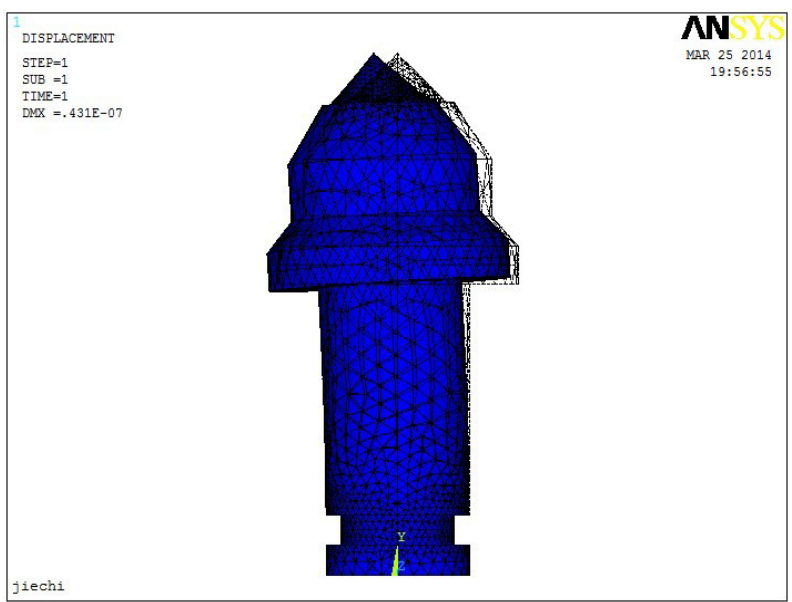

Fig. (4). Deformation of conical pick.

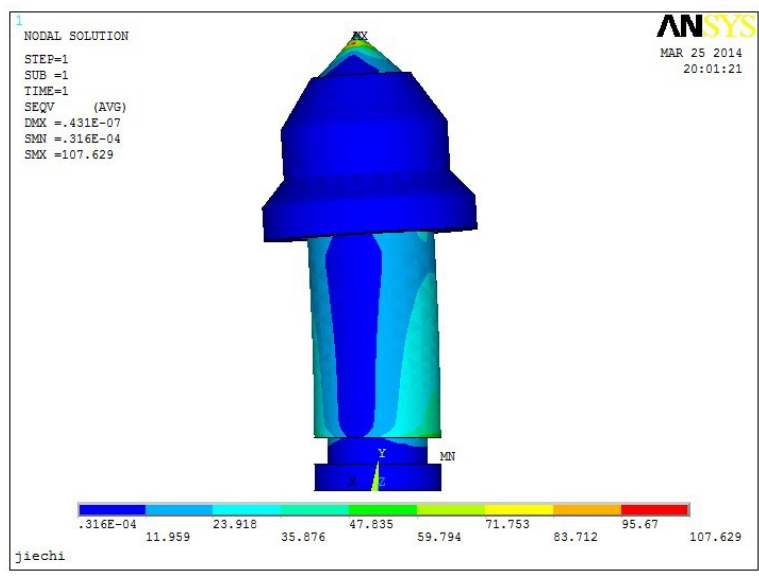

Fig. (5). Von mises stress of conical pick.

It can be seen that the maximum stress of conical pick appeared in the tool bit, and the maximum Von mises stress was $107.629 \mathrm{MPa}$, which was mainly due to the concentrated force on the area.

The Von mises stress is drawn on the surface of conical pick along with axis in Fig. (6). The stress distribution of whole conical pick can be seen. According to the static analysis result, the conical pick is not damaged under static load.

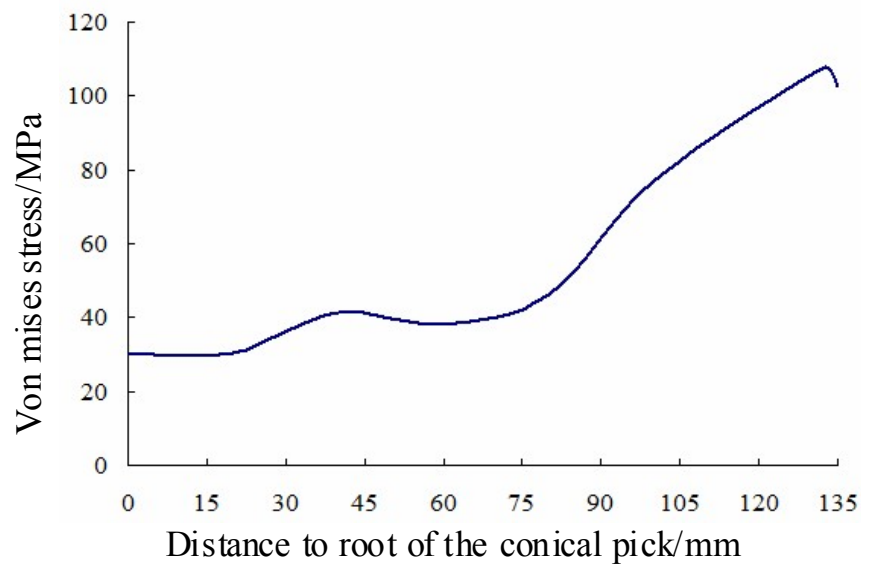

Fig. (6). Load and constraint of conical pick.

The strength of conical pick was analyzed with the method of applying concentrated force on conical pick using the finite element analysis in this section, however, the statics analysis is based on force calculated by empirical formula, and many assumptions were made before the analysis, thus the results of the analysis require further validation.

\section{CONTACT ANALYSIS OF STRENGTH OF CONICAL PICK}

In order to examine the result of statics analysis in the previous section, the method of contact analysis is adopted to analyze the strength of conical pick in this part. The finite element model of the conical pick and coal is built, and contact pairs are established between them. Then, torque is applied to conical pick and constraint is set to coal model, simulating the cutting process of conical pick. 


\subsection{Finite Element Modeling and Meshing of Cutting System}

In order to simplify the analysis model, one conical pick of cutting head and a cuboid with limited volume are built to simulate the coal model. Considering the convergence of contact analysis, the tool bit of conical pick is inserted into coal model and surface contact model is established. Solid185 element type is defined for conical pick and Solid65 for coal model. Contact type is set surface to surface, simulating the contact surface with TARGE170 and CONTA174 contact element with the target surface and contact surface being flexible. The material parameters of coal are defined as: elasticity modulus is $1400 \mathrm{MPa}$, poisson ratio is 0.3 , and the material parameters of conical pick are the same as the previous section. The contact friction coefficient is set as 0.1 .

The conical pick and coal are meshed with smart size (level 6) and the part of contact area is refined, while 211596 nodes and 107792 elements are obtained. The finite element model after meshing is shown in Fig. (7).

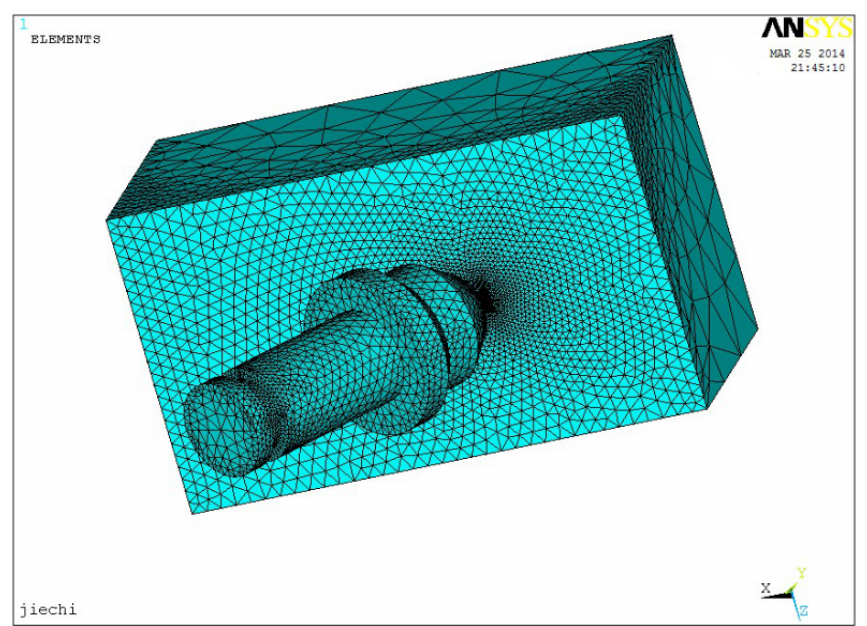

Fig. (7). Finite element model of cutting system.

\subsection{Establishing Contact Pair}

Contact pair is created for the analysis by contact pair set up guide, defining contact element with TARGE170 and CONTA174, and flexible contact pair between tool bit and contact part is built on coal model.

\subsection{Solving and Result Analysis}

Torque is applied to conical pick in the analysis and rigid zone is established between the root of conical pick and center of rotation, and all DOF is set for the coal model. The torque on conical pick can be calculated by the following formula:

$$
P=T \cdot\left(\frac{2 \pi n}{60}\right) / 1000
$$

where $P$ is power of cutting head $(\mathrm{kW}), T$ is torque $(\mathrm{N} \cdot \mathrm{mm})$, and $n$ is rotating speed of cutting head $(\mathrm{r} / \mathrm{min})$.

It is known that the power of cutting head is $220 \mathrm{~kW}$, the rotating speed of cutting head is $36 \mathrm{r} / \mathrm{min}$, so the torque of conical pick is $38361 \mathrm{~N} \cdot \mathrm{mm}$. The finished finite element model of contact analysis with load and constraint is shown in Fig. (8).

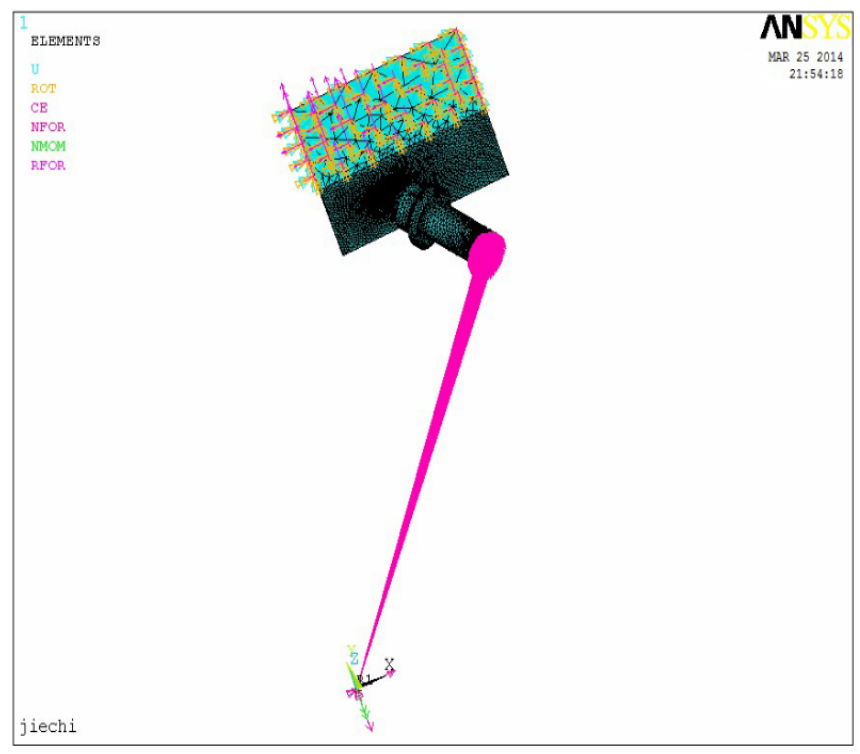

Fig. (8). Load and constraint of contact analysis.

\subsection{Discussion of Analysis Results}

It is hard to observe the stress of conical pick from the whole model due to the small contact area, so the coal model is hidden and only the conical pick is shown to observe the Von mises stress of conical pick by contact analysis, which is shown in Fig. (9).

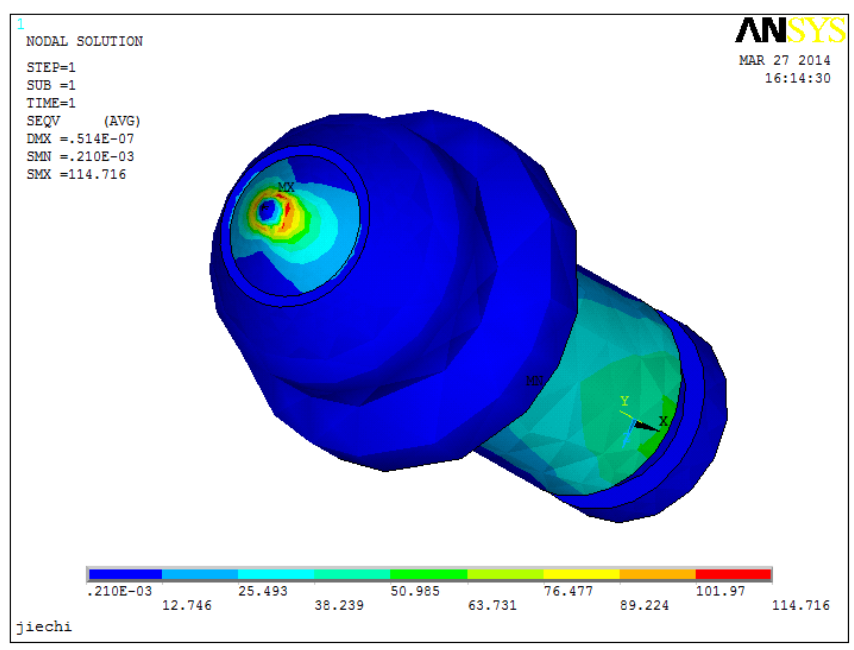

Fig. (9). Von mises stress of conical pick by contact analysis.

It can be seen from the figure that the maximum equivalent stress also occurred in the tool bit which is the same as statics analysis, and the value of the maximum equivalent stress is $114.716 \mathrm{MPa}$ which is approximately equal to statics analysis. The Von mises stress is drawn on the surface of conical pick by contact; analysis along with axis is shown in Fig. (10). It can be seen that the stress distribution of whole conical pick corresponds to statics analysis result as shown in Fig. (6). 


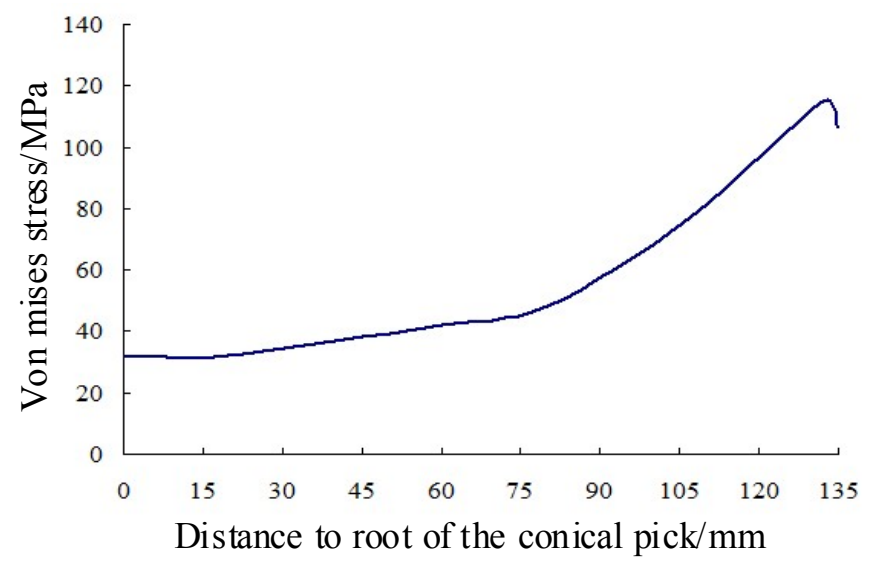

Fig. (10). Von mises stress curve of conical pick by contact analysis.

It can be found that the stress concentration on conical pick really exists and the high stress is one of the significant reasons of cemented carbide tool that falls off and breaks off. At the beginning of the actual mining operation, the wear just occurs at cemented carbide tool since the abrasion increases greatly. The conical pick shoulder contacts with coal and rock increases and the wear accelerates the fall off of the alloy tool bit, leading to conical pick failure. The consistency of statics analysis and contact analysis also shows the rationality of the theoretical formula of force calculation of conical picks.

\section{OPTIMIZATION OF CUTTING ANGLE}

Cutting angle is the angle between the axis of the conical pick and the motion trajectory tangent of the tool bit which has great influence on the strength of roadheader conical picks [13]. With the contact analysis above, different models of cutting systems with different cutting angles can be built and the strength of conical picks for different models can be analyzed in order to find the best cutting angle for the conical pick.

In general, the cutting angle of conical pick is between $40^{\circ}$ and $55^{\circ}$. In order to study the effects of cutting angle on the strength of conical pick and optimize this angle, the finite element model of contact analysis is established with the cutting angles of $40^{\circ}, 43^{\circ}, 46^{\circ}, 49^{\circ}, 52^{\circ}$, and $55^{\circ}$, to simulate the contact analysis and to obtain the maximum equivalent stress in different cutting angles as shown in Table $\mathbf{1 .}$

Table 1. The maximum equivalent stress values in different cutting angles.

\begin{tabular}{|c|c|c|c|c|c|c|}
\hline $\begin{array}{c}\text { Cutting } \\
\text { Angle ( }{ }^{\circ}\end{array}$ & 40 & 43 & 46 & 49 & 52 & 55 \\
\hline $\begin{array}{c}\text { Maximum } \\
\text { Equivalent } \\
\text { Stress (MPa) }\end{array}$ & 142.538 & 134.934 & 112.356 & 130.467 & 145.825 & 150.324 \\
\hline
\end{tabular}

In order to observe the relationship of maximum equivalent stress and cutting angle more clearly, the relation curve is drawn as shown in Fig. (11). From the relation curve, it can be seen that the maximum equivalent stress decreases along with the increase in cutting angle first and then increases along with the increase in cutting angle. So it can be concluded that the best cutting angle is about $46^{\circ}$ for this type of conical picks.

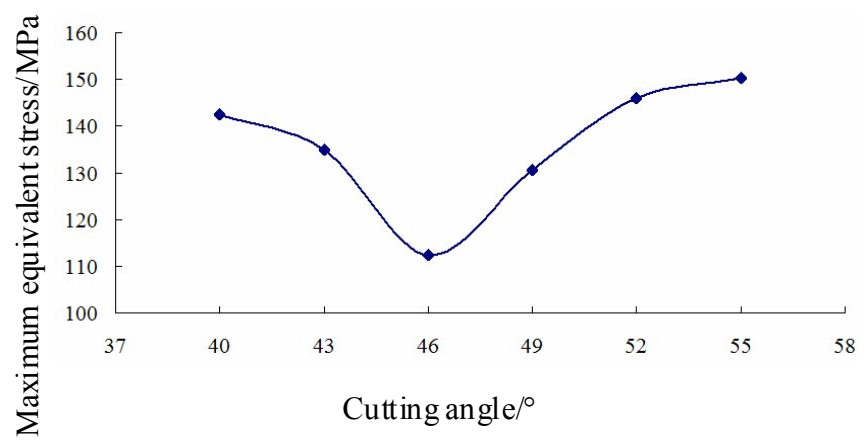

Fig. (11). Relation curve of maximum equivalent stress and cutting angle.

\section{CONCLUSION}

The failure forms of conical picks were researched, mainly including wear of conical picks, cemented carbide tool bit fall off, conical picks loss and so on. The static analysis was carried out according to the load calculated by empirical formula based on ANSYS. In order to examine the result of static analysis, contact analysis of conical pick cutting process was researched. The deformation map and stress distribution of conical pick were obtained respectively and consistency was achieved. The results show that the maximum stress of conical pick appeared in the tool bit and the main deformation also occurred in this area. The finite element analysis of strength of roadheader conical picks has great significance for the improvement of conical pick design and the service life of the pick.

\section{CONFLICT OF INTEREST}

The authors confirm that this article content has no conflict of interest.

\section{ACKNOWLEDGEMENTS}

This work was supported by the National Natural Science Foundation of China (Grant No. 51475440 and 51375282), the Science and Technology Research Guidance Projects of China National Coal Association (Grant No. MTKJ2012348), the Special funds for cultivation of Taishan Scholars, and the Natural Science Foundation of Shandong Province (Grant No. YC140105), and the Science and Technology Development Program of Shandong Province (Grant No. 2014GGX103043).

\section{REFERENCES}

C. J. Su, and X. K. Du, "Quantitive analysis of warm extruding precision forming mechanics model for cutting pick body of coal excavator", Forging \& Stamping Technology, vol. 35 , no. 2 , pp. 89-93, 2010. (in Chinese).

[2] Z. L. Ning, and H. S. Zhu, "Research of stress distribution for conical bits", Journal of Xi'an University of Science and Technology, vol. 23, no. 3, pp. 325-327, 2003. (in Chinese). 
[3] F. L. Ji, T. H. Peng, and X. L. Xu, "Finite element analysis to cutting tooth of transverse tunneler", Mining \& Processing Equipment, vol. 33, no. 8, pp. 19-21, 2005. (in Chinese).

[4] Y. J. An, "Simulation analysis on strength of cutting picks with various shapes based on LS-DYNA", Mining \& Processing Equipment, vol. 39, no. 12, pp. 5-8, 2011. (in Chinese).

[5] X. H. Li, D. Wu, and X. H. Shi, "Finite element analysis on pointattack picks with different shapes based on ANSYS", Journal of Liaoning Technical University (Natural Science), vol. 28, no. 5, pp. 798-800, 2009. (in Chinese).

[6] X. H. Li, B. F. Yin, and H. B. Li, "Experimental researches on cutting with concial picks", Journal of Liaoning Technical University (Natural Science), vol. 18, no. 6, pp. 649-652, 1999. (in Chinese).

[7] O. Su, and N. A. Akcin, "Numerical simulation of rock cutting using the discrete element method", International Journal of Rock Mechanics and Mining Sciences, vol. 48, no. 3, pp. 434-442, 2011.

[8] J. Rojek, E. Oñate, and C. Labra, "Discrete element simulation of rock cutting", International Journal of Rock Mechanics and Mining Sciences, vol. 48, no. 6, pp. 996-1010, 2011.
[9] K. G. Hurt, and K. M. MacAndrew, "Cutting efficiency and life of rock-cutting picks", Mining Science and Technology, vol. 2, no. 2, pp. 139-151, 1985 .

[10] Q. Zhang, and G. Q. Nie, "Experimental research on failure mechanism and wear resistance improvement of heavy cutting teeth", Hot Working Technology, vol. 42, no. 14, pp. 23-26, 2013. (in Chinese).

[11] K. Krauze, and K. Kotwica, "Selection and underground tests of the rotary tangential cutting picks used in cutting heads of the longwall and roadway miners", Archives of Mining Sciences, vol. 52, no. 2, pp. 195-217, 2007.

[12] X. H. Li, The Key Technology Research of the Roadheader Cutting. $1^{\text {st }}$ Edition, Mechanical Industry Press, China, 2008. (in Chinese).

[13] X. Y. Li, B. B. Huang, and C. C. Li, "Dynamics analysis on roadheader cutting head based on LS-DYNA", Journal of Convergence Information Technology, vol. 7, no. 23, pp. 333-340, 2012.

(C) Li et al.; Licensee Bentham Open

This is an open access article licensed under the terms of the Creative Commons Attribution Non-Commercial License (http://creativecommons.org/licenses/by-nc/4.0/) which permits unrestricted, non-commercial use, distribution and reproduction in any medium, provided the work is properly cited. 